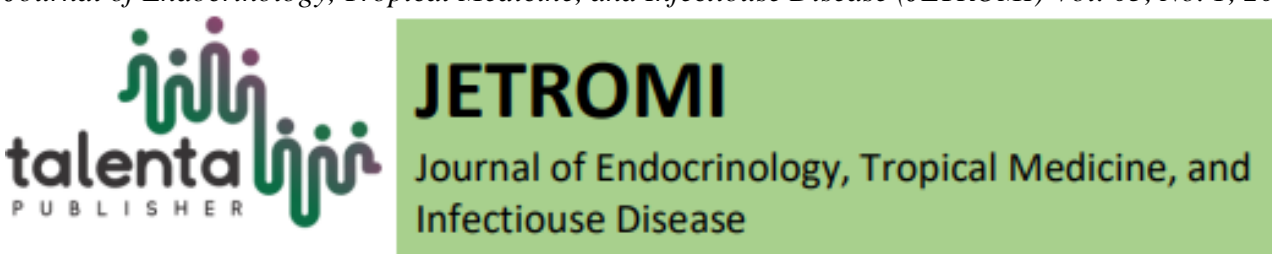

\title{
The Relationship Between Body Mass Index and Inflammatory Parameters in HIV Patients Treated with Antiretrovirals
}

\author{
Lydia Theresia ${ }^{1}$, Dharma Lindarto ${ }^{2}$, Santi Syafril ${ }^{2}$, Tambar \\ Kembaren $^{3}$ \\ ${ }^{1}$ Department of Internal Medicine, Faculty of Medicine, Universitas Sumatera Utara \\ ${ }^{2}$ Division of Endocrinology and Metabolic Disease, Department of Internal Medicine, Faculty of \\ Medicine, Universitas Sumatera Utara \\ ${ }^{3}$ Division of Tropical Infectious Disease, Department of Internal Medicine, Faculty of Medicine, \\ Universitas Sumatera Utara
}

\begin{abstract}
Antiretroviral administration affects weight gain and inflammation in HIV patients. The purpose of the study was to assess the relationship of body mass index with inflamation parameters in HIV patients who ARV therapy. In 40 HIV patients (stage III-IV) treated with ARV (FDC 87\%, Durival Efaviren 7.5\%, Tenofovir, Huviral, Aluvia 2.5\%, and Tenofovir, Huviral, Neviral 2.5\%) conducted observational analytics with crosssectional design. CD4 examination was carried out flowcytometrically, BMI measured by formula weight $(\mathrm{kg}$ ) divided by height squared ( $\mathrm{m} 2$ ), waist circumference (WC) measured by ribbon between costae arcus and anterior superior iliac spine, albumin measurement with Brom Cresol Green (BCG) method. There is a significant correlation between BMI with WC and CD4 ( $r=0.61, p<0.001$ and $r=0.38, p<0.001$, respectively). There is no correlation between BMI and duration of ARV treatment, albumin and leptin. ARV treatment in HIV patients will affect weight and inflammatory markers.
\end{abstract}

Keyword: ARV, Body weight, CD4

\begin{abstract}
Abstrak. Pemberian antiretrovirus akan mempengaruhi berat badan dan inflamasi pada pasien HIV. Tujuan penelitian menilai hubungan indeks masa tubuh dengan parameter inflasi pada pasien HIV yang mendapatkan terapi ARV. Terhadap 40 penderita HIV (stadium III-IV) yang diterapi ARV (FDC 87\%, Durival Efaviren 7,5\%, Tenofovir, Huviral, Aluvia 2,5\%, dan Tenofovir, Huviral, Neviral 2,5\%) dilakukan studi analitik observasional dengan desain crosssectional. Pemeriksaan CD4 dilakukan menggunakan metode flowcytometry, BMI diukur dengan bobot formula $(\mathrm{kg})$ dibagi dengan tinggi badan kuadrat $\left(\mathrm{m}^{2}\right)$, lingkar pinggang (WC) diukur dengan pita antara arcus costae dan SIAS, pengukuran albumin dengan metode Brom Cresol Green (BCG). Terdapat korelasi yang signifikan antara BMI dengan WC dan CD4 ( $r=0.61, p<0.001$ and $r=0.38, p<0.001$, secara berurutan). Tidak terdapat korelasi antara IMT dengan lama pengobatan, albumin dan leptin. Pengobatan ARV pada pasien HIV akan mempengaruhi berat badan dan penanda inflamasi.
\end{abstract}

Kata Kunci: ARV, Berat Badan, CD4

Received 16 January 2021 | Revised 27 February 2021 | Accepted 28 February 2021 \footnotetext{
Indonesia

E-mail address: letting_go02@yahoo.com

*Corresponding author at: Department of Internal Medicine, Faculty of Medicine, Universitas Sumatera Utara, 


\section{Introduction}

An increasing prevalence of overweight and obesity has also been reported in people living with human immunodeficiency virus (PLWH), among whom initiation of antiretroviral therapy (ART) often leads to weight gain [1]. Although this weight gain may be a positive prognostic indicator in PLWH who are underweight at the time of ART initiation, [2] among those in normal or overweight categories, weight gain may increase the risk of cardiovascular and metabolic diseases [3]. Possible mechanisms for ART-associated weight gain include a return-to-health phenomenon, especially in those with advanced human immunodeficiency virus (HIV) disease, with weight returning to a pre-illness baseline. The mechanism underlying the return-to-health phenomenon is incompletely understood, but likely results from the alleviation of HIV-associated inflammation and accelerated catabolism [4]. Treatment of HIV may also hasten resolution of opportunistic infections and gastrointestinal (GI) dysfunction that could adversely affect appetite and nutrient.

Specific ART regimens or drug classes have also been implicated in weight gain, with integrase strand transfer inhibitors (INSTIs) cited in 2 randomized studies [5] and several retrospective cohort studies [6]. Highly active antiretroviral therapy (HAART)-induced lipoatrophy, currently the most common form of lipoatrophy worldwide, is associated with hypoleptinemia, insulin resistance, and elevated triglycerides in the context of the HAART-induced metabolic syndrome (HAART-MS) [7].

Based on this, study will research how the relationship between body mass index and CD4 in HIV patients who get antiretroviral (ARV).

\section{Method}

The study was conducted on 40 HIV patients (stage III-IV), type ARV used is FDC 87\%, Durival Efaviren 7.5\%, Tenofovir, Huviral, Aluvia 2.5\%, and Tenofovir, Huviral, Neviral 2.5\%. This research is based on observational analytical studies with cross-sectional research design, and consecutive sampling of samples that meet inclusion and exclusion criteria. The inclusion criteria are men and women aged 18 to 60 years, HIV-diagnosed and on antiretroviral therapy for at least 2 months, and adhere to drug consumption. The exclusion criteria are HIV patients with comorbidities (diabetes, cardiovascular disease, renal dysfunction, malignancy, and autoimmune disease), opportunistic infection, and hormonal dysregulation. CD4 examination is done flowcitometrically, BMI is measured by formula weight $(\mathrm{kg})$ divided by height squared $\left(\mathrm{m}^{2}\right)$, waist circumference (WC) measured by ribbon between arcus costae and SIAS, albumin measurement with Brom Cresol Green (BCG) method. 


\subsection{Statistical analysis}

A normality test of the data is performed, normal distributed in the form of mean with standard deviation, if not normal distributed prepared in the form with maximum-minimum. The statistical analysis used to assess the relationship of BMI with other anthropometric parameters is Pearson test if the variables are normally distributed and Spearman test if the distribution is abnormal.

\section{Result}

The basic parameters of the research subjects in Table 1.

Table 1. Basic data of HIV patients

\begin{tabular}{lc}
\hline \multicolumn{1}{c}{ Parameter } & Mean \pm SD \\
\hline Age $($ year $)$ & $33.62 \pm 7.61$ \\
WC $(\mathrm{cm})$ & $76.17 \pm 9.87$ \\
BMI $\left(\mathrm{kg} / \mathrm{m}^{2}\right)$ & $21.29 \pm 3.46$ \\
CD4 $\left(\mathrm{cell} / \mathrm{mm}^{3}\right)$ & $330.55 \pm 163.98$ \\
ARV treat $(\mathrm{month})$ & $2.40 \pm 2.34$ \\
Albumin $(\mathrm{gr} / \mathrm{dL})$ & $3.68 \pm 0.82$ \\
Leptin $(\mathrm{ng} / \mathrm{mL})$ & $11.98 \pm 8.32$ \\
\hline
\end{tabular}

In table 2, There is a significant correlation between BMI and WC and CD4.

Table 2. Correlation between BMI and inflammatory parameters

\begin{tabular}{lcc}
\hline \multicolumn{1}{c}{ Parameter } & $\mathbf{R}$ & $\mathbf{P}$ \\
\hline Age (year) & -0.01 & 0.469 \\
WC (cm) & 0.61 & $0.001^{* *}$ \\
CD4 (cell/mm $\left.{ }^{3}\right)$ & 0.38 & $0.001^{* *}$ \\
ARV treat (month) & 0.10 & 0.270 \\
Albumin (gr/dL) & 0.21 & 0.097 \\
Leptin (ng/mL) & 0.18 & 1.32 \\
\hline$* *$ significance & &
\end{tabular}




\section{Discussion}

The causes underlying the progressive rise in body weight among the HIV-infected population are likely a complex mix of interrelated and shifting lifestyle trends in society at large, HIV provider and patient conceptions of health and priorities for care, changes in guidelines for initiating ART, and the introduction of new ART agents, among other factors [8]. It is reasonable to assume that HIV patients are similarly affected by factors driving obesity in the general population, particularly as earlier treatment and effective ART preempt the cachexia common in advanced untreated disease [9].

If individual agents contribute to weight gain aside from tolerability, the mechanisms by which they do so is not known. For treatment-naive PLWH, some of the association between weight gain and INSTI-containing regimens could be their faster virologic control compared to older regimens [10]. Another explanation for drug-specific effects on weight could be off-target biological interactions. One such example is the observed interaction between DTG and melanocortin 4 receptor (MC4R), a receptor involved in the regulation of caloric intake by modulating leptin signaling in the central nervous system [11]. This finding is intriguing as mutations in MC4R are associated with heritable obesity [12]. This potential mechanism requires further validation, and it remains unknown whether other INSTIs interact similarly.

Evaluating the effect of ART drugs on weight gain is confounded by HIV disease factors such as return to health; some of these limitations may be avoided by studying weight changes in preexposure prophylaxis (PrEP) trials. In the Iniciativa Profilaxis Pre-Exposición study comparing TDF/FTC to placebo, the TDF/FTC arm gained less weight than placebo, suggesting that TDF/FTC may have a mild weight-suppressive effect [13]. In the DISCOVER trial of TDF/FTC vs TAF/FTC for PrEP, weight gain at week 48 was $1.1 \mathrm{~kg}$ in the TAF/FTC arm with no change in the TDF/FTC arm [14]. Finally, in a phase 2 placebo controlled trial of cabotegravir for PrEP, both arms ex- perienced about $1 \mathrm{~kg}$ of weight gain over 41 weeks, with no significant difference between arms [14]. Together these findings suggest that heathy participants taking TAF or an INSTI likely experience weight gain much like the general population, which contrasts with the weight-suppressive effect of TDF.

In this studies, there is significant correlation between BMI and WC and CD4 ( $r=0.61, p<0.001$ and $\mathrm{r}=0.38, \mathrm{p}<0.001$, respectively), then the administration of ARVs in HIV patients will affect weight and inflammation marker.There are several limitations of this study. We have data of wide variation duration treatment ART. Our stuies did not evaluate other potential contributors to weight gain such as psychiatric comorbidities, concomitant medications, diet, physical activity, or smoking. In the included trials, newer third agents were generally coadministered with ART. Duration of treatment is an average of two months and BMI status of normoweight-overweight patients. 


\section{Conclusion}

The administration of ARV in HIV patients will affect body weight and inflammatory markers.

\section{REFERENCES}

[1] Bakal DR, Coelho LE, Luz PM, Clark JL, De Boni RB, Cardoso SW, et al., "Obesity following ART initiation is common and influenced by both traditional and HIV-/ARTspecific risk factors", J Antimicrob Chemother, vol. 73, p. 2177-85. 2018.

[2] Bianca Yuh, Janet Tate, Adeel A. Butt, Kristina Crothers, Matthew Freiberg, David Leaf, et al., "Weight change after antiretroviral therapy and mortality", Clin Infect Dis, vol. 60, p. 1852-9. 2015.

[3] Melissa Herrin, Janet P. Tate, Kathleen M, Adeel A. Butt, Kristina Crothers, Matthew S. Freiberg, et al., "Weight gain and incident diabetes among HIV-infected veterans initiating antiretroviral therapy compared with uninfected individuals", J Acquir Immune Defic Syndr, vol. 73, p. 228-36. 2016.

[4] Kumar S, Samaras K., "The impact of weight gain during HIV treatment on risk of prediabetes, diabetes mellitus, cardiovascular disease, and mortality", Front Endocrinol (Lausanne), vol. 9, p. 705. 2018.

[5] Bhagwat P, Ofotokun I, McComsey GA, et al., "Changes in waist circumfer- ence in HIVinfected individuals initiating a raltegravir or protease inhib- itor regimen: effects of sex and race", Open Forum Infect Dis, vol. 5, p. 16. 2018.

[6] Norwood J, Turner M, Bofill C, et al., "Brief report: weight gain in persons with HIV switched from efavirenz-based to integrase strand transfer inhibitor-based regimens", $J$ Acquir Immune Defic Syndr, vol. 76, p. 527-31. 2017.

[7] Aoife M. Brennan, Jennifer H. Lee, Sotirios Tsiodras, Jean L. Chan, John Doweiko, Sonia N. Chimienti, "r-metHuLeptin improves highly active antiretroviral therapy-induced lipoatrophy and the metabolic syndrome, but not through altering circulating IGF and IGFbinding protein levels: observational and interventional studies in humans," Eur J Endocrinol., vol. 160(2), p. 173-176. 2009.

[8] The State of Obesity 2014, Robert Wood Johnson Foundation; 2014, no. Available at http://stateofobesity.org/files/stateofobesity, p. 2014.

[9] Powanda MC and Beisel WR, "Metabolic effects of infection on protein and energy status", J Nutr, p. 322S-327S. 2003.

[10] Jacobson K, Ogbuagu O., "Integrase inhibitor-based regimens result in more rapid virologic suppression rates among treatment-naive human immunodeficiency virus-infected patients compared to non-nucleoside and protease inhibitor-based regimens in a real-world clinical setting", Medicine (Baltimore), vol. 97:e13016, p. 32. 2018. 
[11] Hill A, Waters L, Pozniak A., "Are new antiretroviral treatments increasing the risks of clinical obesity?", J Virus Erad, vol. 5, p. 41-3. 2019.

[12] Adan RA, Tiesjema B, Hillebrand JJ, la Fleur SE, Kas MJ, de Krom M, " MC4 receptor and control of appetite", Br J Pharmacol, vol. 149, p. 815-27. 2006.

[13] Glidden DV, Mulligan K, McMahan V, et al., " Metabolic effects of preexposure prophylaxis with coformulated tenofovir disoproxil fumarate and emtricitabine", Clin Infect Dis, vol. 67, p. 411-9. 35. 2018.

[14] Hare CB, Coll J, Ruane P, et al., "The phase 3 DISCOVER study: daily F/ TAF or F/TDF for HIV preexposure prophylaxis [abstract 104LB]", In: Conference on Retroviruses and Opportunistic Infections, Seattle, WA. 4-7 March 2019. 